HTR 81:I (1988) 19-36

\title{
THE SYNOPTIC GOSPELS AND THE NONCANONICAL ACTS OF THE APOSTLES *
}

\author{
François Bovon \\ University of Geneva
}

\section{INTRODUCTION}

At the end of the second century, four gospels became canonical. Today they are present everywhere in the world at the beginning of the New Testament and at the heart of the Christian Bible, side by side and in the same order, endowed with the same authority. The text of these four gospels has been fixed for a long time, notwithstanding the existence of thousands of textual variants which have troubled European scholars since the eighteenth century. ${ }^{1}$ Today no one dreams of publishing interpolated versions of these gospels or of doctoring our holy books. Biblical scholarship devoted to the study of these gospels now occupies a firm place in the programs of numerous theological faculties and departments of religious studies.

In contrast, with respect to the Christian apocryphal literature, no one knows exactly even what writings should belong to this corpus. The text of these documents has never been fixed. At the same time as Konstantin von Tischendorf was preparing his critical edition of the martyrdoms and apocalypses of the apostles, ${ }^{2}$ a Greek monk from Palestine ${ }^{3}$ was retelling in his own style the same

${ }^{*}$ Lecture delivered at the annual meeting of the Society of Biblical Literature in Atlanta, 24 November 1986, and at the Divinity School, Harvard University, 5 February 1987. I wish to thank Ken McKinney for translating my French text into English.

${ }^{1}$ The John Mill edition of Novum Testamentum cum lectionibus variantibus (Oxford, 1707), by setting out numerous variants, troubled many minds in Europe, including Johann Albrecht Bengel. Cf. Werner Georg Kümmel, The New Testament: The History of the Investigation of its Problems (London: SCM, 1973) 47-48; ET of Das Neue Testament: Geschichte der Erforschung seiner Probleme (2d ed.; Freiburg/Munich: Alber, 1970).

${ }^{2}$ Konstantin von Tischendorf, Acta apostolorum apocrypha (Leipzig, 1851); idem, Apocalypses apocryphae (Leipzig, 1866; reprinted Hildesheim: Olms, 1966).

${ }^{3}$ I am referring to the monk Joasaph of the S. Sabba monastery, who ended his days on Mount 
stories which Tischendorf and R. A. Lipsius and M. Bonnet ${ }^{4}$ were editing. No special scientific discipline has arisen that is devoted to the study of these texts; students of the New Testament, patristic scholars, and historians are the guardians of this orphaned literature.

I propose to modify our perspective. We must learn to consider the gospels of the New Testament canon, in the form in which they existed before $180 \mathrm{CE}$, in the same light in which we consider the apocrypha. At this earlier time the gospels were what the apocrypha never ceased to be. Like the apocrypha, the gospels of the New Testament were not yet canonical; they did not circulate together ${ }^{5}$ and when they did, they did not always appear in the same sequence. ${ }^{6}$ Moreover, these gospels were not the only ones in circulation: other gospels had been born. Furthermore, their texts were subject to scholarly recension (especially Luke-Acts). Readers improved them, harmonized them (Tatian), pruned them, and supplemented them. Many made them into sacred writings in ways not necessarily desired by their original authors. Certain people would soon enshrine them in a canon which, according to Franz Overbeck, ${ }^{7}$ resulted in a loss of meaning. Orthodox and heterodox theologians from Marcion to Origen, partisans as well as adversaries of Christianity from Celsus to Porphyry, all attest to transformation of these gospels in their early period of transmission. They were not secured until the time of Irenaeus. ${ }^{8}$ Familiarity with texts which were never made sacred, like the apocryphal acts of the apostles, will be fruitful for the study of documents like the canonical gospels as they existed for more than a century prior to their eventual canonization.

\footnotetext{
Athos. His work, calligraphed in a large folder is dated 2 May 1879. It bears the figure Z 59 in the Library of the Megali Lavra in Athos.

${ }^{4}$ Concerning the Tischendorf editions, cf. $n$. 2 . The nineteenth-century investigations culminated in the R. A. Lipsius and M. Bonnet edition, Acta apocrypha (3 vols.; Leipzig, 1891-1903; reprinted Darmstadt: Wissenschaftliche Buchgesellschaft, 1959).

${ }_{5}^{5}$ To take one example, the codex of the papyrus $\mathbf{P}^{75}$ contained but two of our four Gospels. Cf. the Victor Martin and Rodolphe Kasser edition, Papyrus Bodmer XIV-XV, vol. 1: Évangile de Luc, chap. 3-24; vol. 2: Évangile de Jean, chap. I-15 (2 vols.; Bibliotheca Bodmeriana; ColognyGeneva: Bibliothèque Bodmer, 1961).

${ }^{6}$ The bilingual (Greek and Latin) Codex Bezae $(D=05)$, as well as several of the most ancient witnesses of the Latin versions, the Palatinus $(2=e)$, Vercellensis $(3=a)$, Veronensis $(4=b)$ codices contain the Gospels in what is called the Western order: Matthew, John, Luke, Mark. Cf. L. Vaganay and Ch.-B. Amphoux, Initiation à la critique textuelle du Nouveau Testament (Études annexes de la Bible de Jérusalem; Paris: Cerf, 1986) 37-39, 51-52.

${ }^{7}$ Cf. F. Overbeck, Zur Geschichte des Kanons, Zwei Abhandlungen (Chemnitz; 1880; reprinted Darmstadt: Wissenschaftliche Buchgesellschaft, 1965) 1.

${ }^{8}$ Irenaeus Adv. haer. 3.1.1. Cf. H. Merkel, La pluralité des Évangiles comme problème théologique et exégétique dans l'Église ancienne (trans. J.-L. Maier; Traditio Christiana 3; Bern: Lang, 1978) 4-5.
} 
Such a new perspective will also allow us to focus our attention on these gospels during the period before their general circulation, on their redaction, and on the time at which their sources were written. This change of view will force us, perhaps unwillingly, to notice that the Evangelists freely practiced what heretics were later accused of doing by the Church Fathers, that is, manipulating the sources which told about Jesus and dipping into earlier documents before these were left to oblivion. We know that they adapted and modified their sources, but because their writings are now canonical we deem their deliberate interventions as faithful, successful, legitimate. After all, it was necessary to adapt earlier texts to new contexts. Although we realize that legends about Jesus were already developed in these very gospels, our judgment remains generally favorable. But why are Matthew's modifications of Mark legitimate and Marcion's modifications of Luke disastrous? Obviously, our judgments concerning these documents are colored by a certain notion of canon.

It is not my intention to be an iconoclast, or to threaten the integrity of the canon. I simply want to underscore the historical fact that the corpus of the canonical gospels did not exist until the end of the second century. The constitution of this corpus was a slow process. ${ }^{9}$ In their arguments for the integrity of the canonical writings, the Fathers obscured the memory of these elaborate beginnings, the alterations of older sources made by the Evangelists as well as the subsequent modifications of their work made by those who come later. One and the same literary practice is shared by the Evangelists and by their successors. It is by observing the successors at work-and the workshop is still open-that we will be able to reconstruct the practice of the Evangelists whose workshop is now closed.

In order to assess the advantages and hazards of the suggested change of perspective, I have chosen examples from fields which I myself have been tilling for a long time, namely, the work of Luke and the noncanonical acts of the apostles, particularly the Acts of Philip (Acts Ph.).

\section{THE PACKAGING AND THE PRODUCT}

Biblical scholars spend most of their time in front of a modern edition of the New Testament. I propose that exegetes, in particular editors of apocrypha, return to the manuscripts themselves. Nothing can replace direct contact with these documents or access to the modus operandi of the scribes and to the demands which influenced their work. One need not be a codicologist to

\footnotetext{
${ }^{9}$ Outside the canon histories, I know of no studies concerning the formation of the first collections of the Gospels like Kurt Aland's study, "Die Entstehung des Corpus Paulinum," in idem, Neutestamentliche Entwürfe (ThB 63; Munich: Kaiser, 1979) 302-50. I did not gain access to E. Preuschen's Zur Vorgeschichte des Evangelienkanons (Darmstadt: Jahresbericht des LudwigGeorgs-Gymnasium, 1925).
} 
become infected by the virus: it is enough simply to be interested. I was convinced, not by hundreds of erudite pages, but by a visit to the library of Lavra (Mt. Athos) of the importance of the lectionaries, written in capital letters, which New Testament textual criticism has far too long neglected. ${ }^{10}$

One must consider the external structure of the manuscript. It is necessary to establish connections of the scriptorial practices of the Christian scribes with their theological convictions on the one hand and with the ecclesiastical constraints under which they were working on the other. ${ }^{11}$ To alter our perspective implies that we remind ourselves of what is still a "curious thing" 12 -that only five of the 274 uncial manuscripts transmit the New Testament in its totality. While "New Testament" suggests a fixed corpus, its constituent parts belong to a more fluid manuscript tradition of the first two centuries.

To study a manuscript containing a collection of hagiographic or homiletical writings involves establishing the table of contexts, the listing and identitying its parts observing incipit, desinit (termination), inscriptio, subscriptio and all other indicators (colophon, etc.). For instance, the subtitles of the Epistles of Peter, in the margin of $\mathbf{P}^{72}, 13$ will strike anyone who has seen the manuscript as a thirdcentury interpretation. Yet these subtitles have been overlooked until now: they do not appear in the Nestle-Aland Novum Testamentum Graece nor in the UBS Greek New Testament ${ }^{14}$ which show little interest in these indicators. The title at the end of the work, the subscriptio, was important in antiquity; why do the editors fail to mention the titles at the end of the Gospel of Luke and the Acts of the Apostles?

Turning to the noncanonical acts of the apostles, one notes that these works, most often in fragmentary form, are inserted in hagiographic compilations and lives of the saints. The titles of these documents vary: "act" or "acts," "travels," "life and martyrdom" appear in turn. The ancient numbering of the acts (e.g., in the Acts $P h$.) is generally eliminated whenever a scribe copies just one of the acts from his source (be it Acts Ph. 2 or more often, the martyrdom; Acts

${ }^{10}$ While in the United States there had been long-term interest in the lectionaries, European scholars only began to pay attention to them after J. Duplacy. Cf. J. Duplacy, "Les lectionnaires et l'édition du Nouveau Testament grec,"' in A. Descamps and A. de Halleux, eds., Mélanges Bibliques en hommage au R. P. Béda Rigaux (Gembloux: Duculot, 1970) 509-45.

${ }^{11}$ Cf. C. H. Roberts and T. C. Skeat, The Birth of the Codex (London, 1983; reprinted London: Oxford University Press, 1985).

${ }^{12}$ Vaganay and Amphoux, Initiation, 35.

${ }^{13}$ Cf. M. Testuz, Papyrus Bodmer VII-IX. VII: L'Épitre de Jude; VIII: Les deux Épitres de Pierre; IX: Les Psaumes 33 et 34 (Cologny-Geneva: Bibliothèque Bodmer, 1959).

14 Cf. Nestle-Aland, Novum Testamentum Graece (25th ed.; Stuttgart: Deutsche Bibelstiftung, 1979) 246, 408; Kurt Aland, Matthew Black, Bruce M. Metzger, and Allen Wikgren, eds., The Greek New Testament (Stuttgart: United Bible Societies, 1966) 319, 528. 
Ph. 8 is an exception). ${ }^{15}$ This inconsistency demonstrates the instability of the notions of canon and text-a weighty argument against the reassuring statement of Martin Hengel, who points to the stability of the titles in the manuscript tradition of the New Testament. ${ }^{16}$ For the simple fact that we have no codices (with inscriptio and subscriptio) of these gospels predating their canonization, the variety of titles no longer appears. The Gospel of Matthew could have been

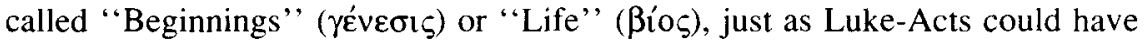

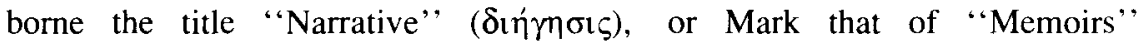
(iro $\mu v \eta \mu \alpha \tau \alpha$ ). At the end of the canonical Acts of the Apostles a manuscript could have preserved the original title of the entire two-volume work. The example of the Acts of Andrew ${ }^{17}$ leads to the following two-fold conclusion: the gospels of the New Testament, in their earliest manuscripts, had titles; but the titles which they now have are the result of an effort of stabilization and they are therefore secondary.

\section{THE SELECTION AND THE ELIMINATION OF SOURCES}

One should not underestimate the constraints weighing on the scribes and limiting their freedom. Redaction is a deliberate process: whether a text is reproduced, discarded, partially preserved, or eliminated, is not unintentional. Theological orientation, literary sensitivity, ecclesiastical pressures, and material constraints govern such decisions.

Consider the example of the Acts of John, which survived severe condemnations by Eusebius of Caesarea, the Second Council of Nicaea, and the Patriarch Photius. ${ }^{18}$ Why was this work preserved? Despite its proclaimed heretical character, the Acts of John transmitted valuable accounts concerning this venerated apostle, especially the story of his death.

${ }^{15}$ Cf. M. Bonnet, "Acta Philippi" in Lipsius and Bonnet, Acta Apocrypha 2. 1-90; and F. Bovon, "Les Actes de Philippe" in idem, ed., Les Actes apocryphes des apôtres. Christianisme et monde paien (Publications de la Faculté de théologie de l'Université de Genève 4; Geneva: Labor et Fides, 1981) $301-05$.

${ }^{16}$ Cf. M. Hengel, Die Evangelienüberschriften (SHAW.PH 1984, 3; Heidelberg: Carl Winter, 1984).

${ }^{17}$ This concerns the conclusion of the Greek Acts of Andrew (AAGr 65, according to the numbering of J.-M. Prieur). While waiting for the critical edition of J.-M. Prieur, cf. Th. Detorakis, "Tò

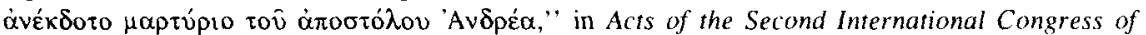
Peloponnesian Studies, published in Peloponnesiaca Journal of the Society of Peloponnesian Studies, Supplement 8; Athens, 1981-82) 352 (concerning lines 728-33).

${ }^{18}$ Photius, Bibliothèque, Codex 114. Cf. R. Henry, Photius Bibliothèque, vol. 2 (Paris: Les Belles Lettres, 1960) 84-86; E. Junod, "Actes apocryphes et hérésie: le jugement de Photius,' in Bovon, ed., Actes apocryphes, 11-24. Another text, the Acts of John by Ps-Prochorus, survived the centuries unmenaced. A recent study, as yet unpublished, of the Greek MS tradition this text has allowed the indexing of about 150 MSS. Cf. E. Junod and J.-D. Kaestli, Acta lohannis (CCSA 1; Turnhout: Brepols, 1983) 3-8. 
Sections of the original Acts of John have survived in texts containing accounts of the apostle, especially in the Acts of John of Ps-Prochorus. How were these sections incorporated into other writings? Two main procedures, substitution and interpolation, can be discerned. In certain cases, the older story of the death of John, the Metastasis, was simply substituted for the story appearing in the Acts of Ps-Prochorus. ${ }^{19}$ In other cases, entire sections were inserted into the text of Ps-Prochorus's work. ${ }^{20}$ The compiler, who implanted large extracts of the original Acts of John into his copy of the Acts of Ps-Prochorus, was forced to recast the entire outline of the latter. ${ }^{21}$

The case of the Acts of John illuminates what must have happened in the process of the production of the canonical gospels. The authors of the Synoptic Gospels intentionally saved all or parts of their sources dear to them. Matthew preserved almost all of the content of Mark, but he sometimes rearranged the order and apparently wanted to render Mark dispensable. ${ }^{22}$ In canonizing Mark, the church disregarded Matthew's intentions as well as his disapproval of some of Mark's wording and order. Luke, who alternated his sources in the composition of his gospel, ${ }^{23}$ was obliged to adapt the sequence of these sources in order to create greater continuity. Luke 6:12-19, where the inversion of Mark 3:7-12 (summary of healings) and Mark 3:13-19 (calling of the Twelve), appears just before the insertion of a section from the Synoptic Sayings Source (Q). Our understanding of the transmission of the apocrypha in ancient manuscripts enhances our ability to analyze the Synoptic Gospels. It forces those of us who were raised in the seraglio of Formgeschichte to pay renewed attention to the use of written sources (source criticism) in these gospels.

In late antiquity, the preservation of certain works often required the discarding of others. Liturgical constraints demanded the abridgment of longer texts. The accounts of the apostles' martyrdom, most valuable for the reader, were frequently extracted at the expense of the less moving peregrinatio. A precious colophon ${ }^{24}$ specifies that the Martyrdom of Philip was to be read in church, whereas the narratives of his life were considered appropriate distraction for

${ }^{19}$ New York, Morgan Library, Coptic MS 576 and Paris, Bibliothèque Nationale, Coptic MS $129^{17}$.

${ }^{20}$ E.g., the Acts of John, 18-55; 58-86; 106-15, inserted in the Acts of John by Ps-Prochorus, according to several MSS edited by Junod and Kaestli, Acta Iohannis, 1:4-7.

${ }^{21}$ Cf. Junod and Kaestli, Acta lohannis, 1:5: "The compiler who took the initiative of adding large extracts of the primitive AJ [= Acts of John] to the text of AJPr [= Acts of John by PsProchorus] was constrained to rework the outline of the latter."

22 This naturally rests on a hypothesis, but a very likely hypothesis, which is defended by Merkel, Pluralité des Évangiles, viii.

${ }^{23}$ Cf. B. H. Streeter, The Four Gospels: A Study of Origins Treating of the Manuscript Tradition, Sources, Authorship, and Dates (London: Macmillan, 1924) 199-200, who notes this alternance and supposes the existence of a "Proto-Luke."

${ }^{24}$ See the MS of Athos, Xenophontos, 32, fol. $29^{\circ}$. 
monks during their frugal meals. In this instance, however, the latter narratives did not disappear from the manuscript but were moved to a secondary position.

Statements of this kind are confirmed for the canonical gospels by the existence of lectionaries. However, moving back into an earlier period, we can apply such observations mutatis mutandis to the gospels themselves and to their relationship to their sources. The practice of extraction and selection would have shaken the confidence of such men as Herder and Gunkel ${ }^{25}$ for whom the shortest text was the oldest and purest. Constraints of which we are not aware or can only surmise may have caused amputations of the most beautiful biblical stories. Evolution does not always proceed from the simpler to the more complicated. Mark must be the oldest gospel not because it is the shortest of the three Synoptic Gospels, but because it is the most simple from a literary perspective.

Any insertion from a source into a more comprehensive document requires a corresponding rearrangement of the text into which the insertion is made. An example from the Acts $P h$. is instructive. The adapter who extracted the martyrdom account from another source had to make sure that what thus became a new document had a beginning. ${ }^{26} \mathrm{He}$ furnished this by writing a historical account which he provided with an imposing synchronism, thus betraying a historicizing concern as well as literary pretensions. Should we not interpret the synchronism of Luke 3 in the same way? It would indicate the use of a new source, commencing at this point, the creation of an "effect of reality" by providing a date, and it would reveal literary pretensions with respect to the style of the account.

\section{THE USE OF SOURCES}

Another phenomenon in the use of sources frequently occurs alongside selection and elimination: adaptation. L. Silberman's work on Jewish literature ${ }^{27}$ and P. Vidal-Naquet's study of Flavius Josephus ${ }^{28}$ have taught us that ancient historians frequently arranged and rearranged the material of their sources on the basis of doctrinal or ideological criteria. In the case of the apocrypha and the canonical gospels, it is necessary to distinguish between citation, imitation, and adaptation. Acts Ph. Martyrdom cites the story of the daughter of Peter

${ }^{25}$ Cf. H. Gunkel, "Literaturgeschichte, 2," $\mathrm{RGG}^{2}$ III 1678. Citations of J. G. Herder in Kümmel, Das Neue Testament, $97-98$.

${ }^{26}$ This concerns $\S \S 107-8$ in the Bonnet edition "Acta Philippi," 41.

${ }^{27}$ L. Silbermann, ' 'Habent Sua Fata Libelli': The Role of Wandering Themes in Some Hellenistic Jewish and Rabbinic Literature," in W. O. Walker, ed., The Relationship among the Gospels: an Interdisciplinary Dialogue (San Antonio: Trinity University Press, 1978) 195-218.

${ }^{28}$ P. Vidal-Naquet, "Du bon usage de la trahison," in Flavius Josephus, La Guerre des Juifs (trans. P. Savinel; Paris: Minuit, 1977) 7-115. 
from the Acts of Peter which Acts Ph. 2 manifestly imitates: the description of Philip in Athens bears the features of Paul's appearance in that city as described in Acts $17 .{ }^{29}$ Acts Ph. 5-7, on the other hand, adapts a long section from the Acts of Peter (a scriptural quotation).$^{30}$ All three techniques, citation, imitation, and adaptation, are methods which reveal the use of written documents.

Applying these observations to the Synoptic Gospels reintroduces attention to the use of written sources, alongside our continuing application of form-critical analysis. One wonders, for example, what Luke's appraisal of Mark was. What status did he give to his source? It should not surprise us that Luke could attribute the same saying in one case to John the Baptist (Luke 3:16) and in another instance to Jesus (and Acts 1:5; 11:16), nor that the same story (e.g., the purification of the Temple, Mark 11:15-17 and par.) could appear in such dissimilar forms in the different gospels, nor that Mark and Q present similar and yet very different sections about John the Baptist (Mark 1:1-11; Luke 3:1-22).

The process of adaptation is best illuminated when one observes the rewriting of the same document by several adapters. With respect to the Alexandrian and Western text of the canonical Acts of the Apostles, the current tendency, at least in France, is to consider both texts as different examples of the adaptation of the same document. ${ }^{31}$ And if one accepts the two-source hypothesis and compares the parallel sections, one can discern the different ways in which Matthew and Luke adapt their common sources Mark and Q. Their work, of course, cannot be understood as a simple compilation of sources, but both writings still belong to the same category of literature as their their sources. The modern editor of apocryphal literature is confronted with the same phenomenon of adaptation. Since this work is less burdened by theological presuppositions, the biblical scholar can learn from it to reflect on the merits and deceptions of the arrangement of related texts in parallel columns (synopses). I want to consider here in more detail the example of the Martyrdom of Philip which, like the Metastasis of John, circulated in three different forms or recensions. The following passage from the Acts $P h$. can be presented in the form of a synopsis, analogous to the customary presentation of the Synoptic Gospels. ${ }^{32}$

${ }^{29}$ Acts Ph. $2 \S \S 6-29$ and Acts Ph. Martyrdom collections $\Theta$ and $\Delta \S 142$; cf. Bonnet, "Acta Philippi," 81.

${ }^{30}$ Acts Ph. $6 \S \S 64-86$; cf. Bonnet, "Acta Philippi," 26-34; Acts of Peter 23-28 (Acta Vercelli).

${ }^{31}$ Several have gone so far as according the priority to the Western text; cf. M.-E. Boismard and A. Lamouille, Le texte occidental des Actes des apôtres. Reconstitution et réhabilitation (2 vols.; Synthèse 17; Paris: Recherche sur les Civilisations, 1984). Cf. Vaganay and Amphoux, Initiation, 41 , concerning the $0171 \mathrm{MS}$ which is close to $\mathrm{D}(=05)$.

32 The ties between the three forms of the Martyrdom of Philip have been examined by J. Flamion, "Les trois recensions grecques du Martyre de l'apôtre Philippe," in Mélanges d"histoire offerts à Charles Maller à l'occasion de son jubilé de 50 années de professorat (1863-1913) (Université de Louvain, Recueil de travaux publiés par les membres des conférences d'histoire et de philologie 40; 
The section I have selected (see the following pages) tells how the apostle John enters the city where his companion Philip is being martyred. Ignorant of what is going on, he asks the people the reason for this agitation ( $\theta$ ó $\rho v \beta o \varsigma)$. A citizen, surprised by his ignorance, tells him the story of Philip's stay in the city, his missionary activities, and his trial.

Even a first glance at this synopsis shows that the recensions $\Gamma$ and $\Delta$ are neighbors: both omit lines $11-16$, the allusion to sexual continence, and they ignore lines 24-30, the recollection of the miraculous healing of Stachys by the saliva of Mary (just as Matthew and Luke have omitted Mark 8:22-26, the healing of a blind man by the spittle of Jesus). Stricter than $\Delta, \Gamma$ also omits lines $30-40$, the section concerning the animal converts. In this case, $\Delta$ comes close to $\Theta$ and even adds to it. One can discern the relationship between these versions and also sense their tendency: $\Gamma$ and $\Delta$ are dependent upon the same source, which is distinct from $\Theta$. But $\Gamma$ presents an even more purified stage of the narrative, while $\Delta$ incorporates elements (lines 33-40) originating from another source (the prayer of the animals) - or even invents this additional section. If one reads the redactional parts of the Synoptic Gospels, one must ask the same question: do the Evangelists create new materials or do they draw additional materials from a different source?

The tradition-redaction phenomenon is verified when the common source of $\Gamma$ and $\Delta$ is compared to $\Theta$. The tradition existed in written form, but did not exclude oral elements. Moreover, the the redaction also allows us to identify its tendency: it edits the text in an orthodox direction. What is important in the judgment of the redactor of $\Gamma$ is not the question of historical truth as seen by modern exegetes, but an ideological orientation. We must, therefore, conclude that also for the authors of the Synoptic Gospels their editing (even in the case of Luke) was less motivated by historical exactitude than by their doctrinal orientation. Furthermore, it is by no means certain that one of the three Synoptic Gospels served as Vorlage for the other two. In the case of Acts Ph. it is necessary to assume a common Vorlage for two of the three recensions, which must then be compared with the third recension. Their minor agreements are so striking that it is necessary to assume their dependence upon another document which is not preserved. Father Boismard's overly complicated Synoptic source hypothesis, ${ }^{33}$ his joy and my irritation, may prove to be right after all. Perhaps there were intermediary stages of written sources; perhaps Matthew and Luke used a version of the Gospel of Mark that was earlier than, and different from, our canonical Mark.

Louvain-Paris, 1914) 1. 215-25. In the case of the Acts of John 106-15, cf. Junod and Kaestli, Acta Iohannis, 317-43.

${ }^{33}$ Cf. P. Benoit and M.-E. Boismard, Synopse des quatre Évangiles en français (Paris: Cerf, 1972) 2. $15-59$. 

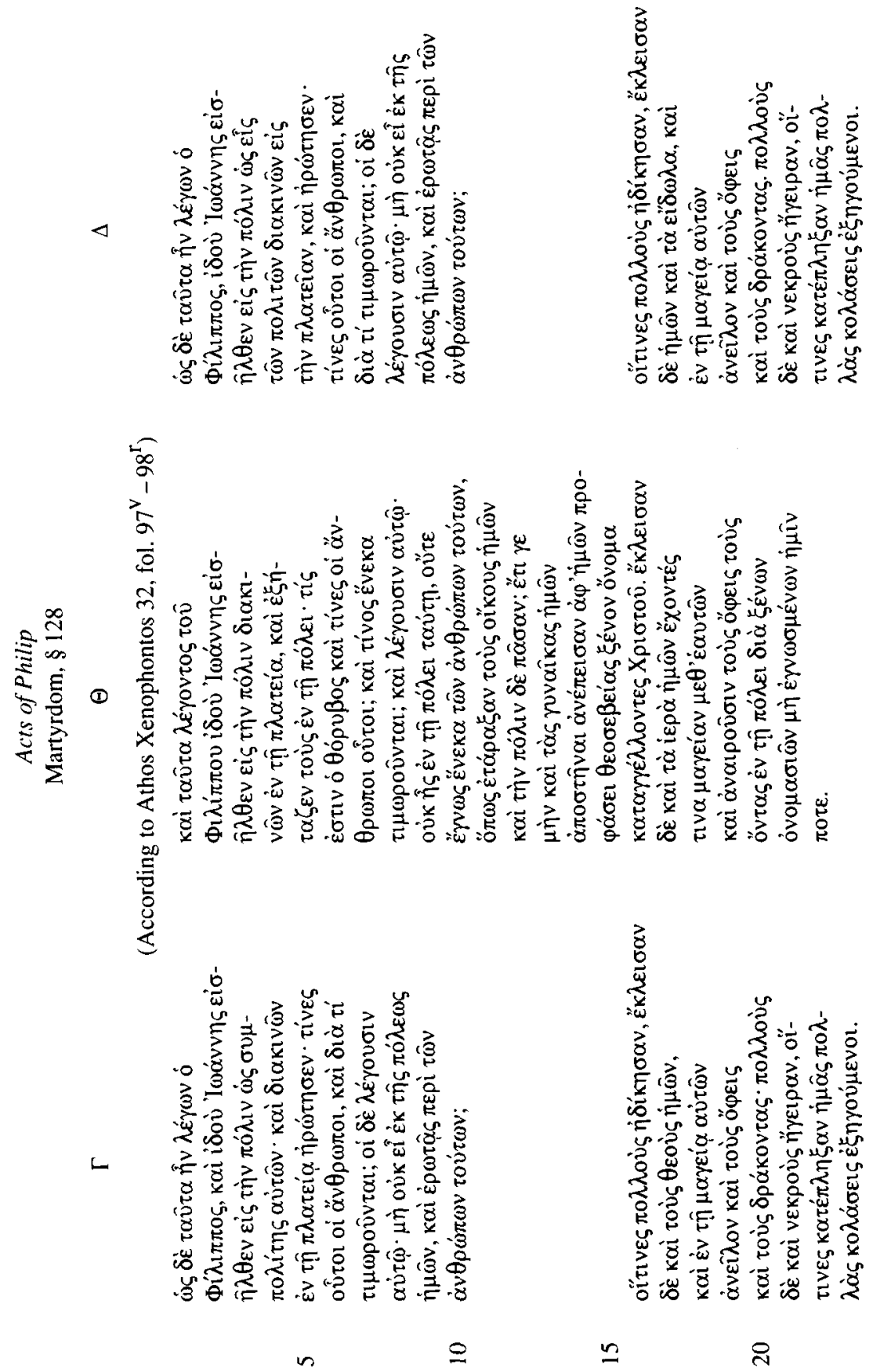

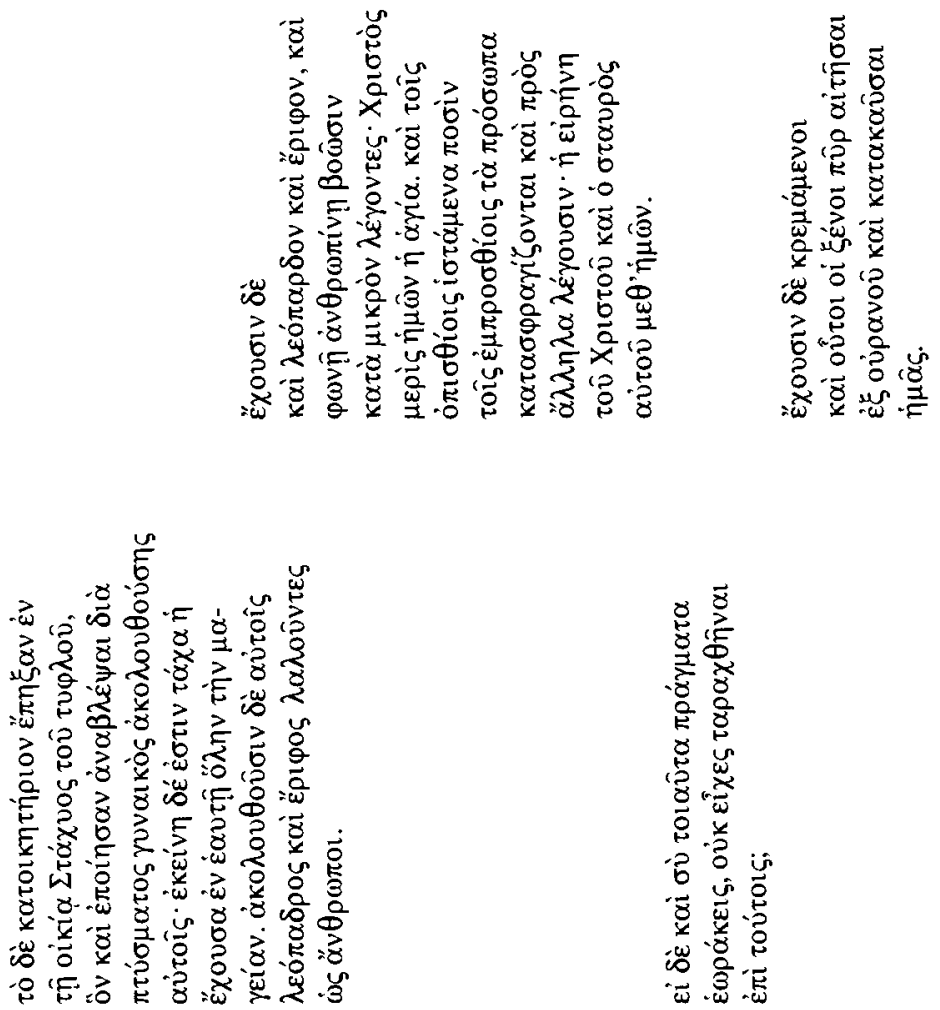

$\ddot{2}$

$$
\stackrel{p}{m}
$$

$\ddot{m}$

F

$\nLeftarrow$ 


\section{THE TRANSMISSION OF THE SAYINGS}

In the canonical gospels as well as in the apocrypha one must treat the sayings and speeches differently from the narrative sections. In the case of the sayings, the wording is more durably and, in general, more scrupulously preserved in the oral tradition. However, this is also the place where certain forms (the parable, for example) offer such evidently solid types that they can stimulate creations of analogous materials. As far as sayings are concerned, the contributions of the noncanonical acts go well beyond purely methodological interests. Because of the stability of the transmission of the sayings, it is quite possible that the noncanonical acts preserved archaic sayings; the genetic method (Überlieferungsgeschichte) could allow us to trace such sayings back into the apostolic or pre-apostolic times.

Three different types can be discerned in analogy to the techniques observed in the narrative materials. Again, adaptation is the most frequent technique. In order to write a speech of an apostle, an author would adapt a discourse from another apocryphal book. One such example is the still unpublished conclusion of Acts Ph. 11: during a Eucharistic ceremony, "Philip" adapts without warning the famous hymn of Christ from the Acts of John.

The second instance concerns a citation. During an appearance to Philip, the Savior speaks with words which recall the style of the sayings of the Synoptic Gospels, particularly that of Q:

At that moment, the Savior appeared and said to Philip: "Who is the one that puts his hand to the plow, then looks back and makes his row straight? Or who is the one who gives his lamp to others, and then himself remains sitting in the darkness? Or who is the one who lives on a pile of manure and leaves his habitation to foreigners? Or who is the one who undoes his clothes, and goes into the hard winter? Or which enemy rejoices in the joy of the one who hates him? Or which soldier goes into the war well-armed and does not put on the vestment of victory? Or which slave, having fulfilled the service of his master, will not be invited by the latter to the meal? Or which athlete runs with ardor in a stadium and does not receive the prize, $O$ Philip? Here, the wedding chamber is ready, blessed is the guest of the spouse, for rich is the harvest of the fields and blessed is the worker who is able." 34

Surprisingly, these sayings of sapiential character do not correspond to any known gospel. A new area of research is opening up here: to complete the collection of Agrapha by A. Resch, who has not yet able to use the edition of the

${ }^{34}$ I translate from a MS of Athos, Xenophontos, 32, fol. $100^{\mathrm{V}}-101^{\mathrm{r}}$, from Acts Ph. Martyrdom collection $\Theta \& 135$; cf. Bonnet, “Acta Philippi," 66-67. 
Acts $P h$. of M. Bonnet. ${ }^{35}$ The relevance of these sayings for the study of the Synoptic Gospels depends upon the degree to which they can be established as "traditional." The apocrypha of the fourth century may indeed quote ancient texts which have not survived. The sayings in this speech of Jesus are no doubt quotations- "invented" speeches of the Savior or of an apostle have a completely different flavor. But from which work are these quotations drawn? from which older collection of logia?

The third instance concerns imitation: a certain type of saying that is characteristic for the sayings of Jesus in the Synoptic Gospels is attributed to an apostle by the noncanonical acts. One might consider, for example, the beatitudes. An unpublished passage from the Acts $P h$. permits us to substantiate that the beatitude survived as a literary genre in apocryphal writings. As in the Acts of Paul, these beatitudes are not attributed to Jesus, but to an apostle, in this case to Philip:

Hearing these words, Philip began to teach: "Blessed are those who follow uprightly the word of Jesus, for they will inherit the earth; blessed are those who repudiate the glory of this world, for they will be glorified; blessed are those who welcome the word of God, for they will inherit incorruptibility." With these words from Philip, all were filled with joy. ${ }^{36}$

What date should be given to these beatitudes? In what kind of milieu did they originate? The expression "word of Jesus" is surprising: is it an archaism? The phrases "follow uprightly" and "repudiate the glory of this world" evoke a rigorous type of Christianity which is familiar to Matthew ("inherit the earth"), John ("be glorified"), possibly Luke ("welcome the word of God"), and Paul ("inherit incorruptibility"). The moralism of this text, just as of similar texts from the Acts of Paul and Matthew, demonstrates that Pauline theology remained marginal in many places. Rather, second-century Christianity was, above all, concerned with discipline; the requirements of the Sermon on the Mount won out over the Pauline kerygma. Might this already be true for certain currents of first-century Christianity? Do we really have to postulate that the community of $\mathrm{Q}$ was based on the kerygma of cross and resurrection?

35 A. Resch, Agrapha. Aussercanonische Schriftfragmente gesammelt und untersucht in zweiter völlig neu bearbeiteter durch alttestamentliche Agrapha vermehrter Auflage herausgegeben (TU n.s. 15.3-4; Leipzig: Hinrichs, 1906) 279-81. These quotations from the Acts Ph. come from the editions which were aware of only a part of the Acts Ph. and are older than Bonnet, "Acta Phlippi."

${ }^{36}$ Athos, Xenophontos 32, fol. $58^{\mathrm{r}}$. The equivalent, but very different passage in the Vaticanus gr. 824 is Acts Ph. $5 \S 63$. It is edited by Bonnet, "Acta Philippi," 26. 


\section{THE INTEGRITY OF THE GOSPELS}

If the conditions under which the Synoptic Gospels were circulating before $180 \mathrm{CE}$ are comparable to that of the later apocrypha, if Matthew and Luke used the same editorial methods as the authors of the apocrypha, and if the first scribes who copied the Synoptic Gospels at that time had the same liberty that we have observed among those who copied apocryphal or hagiographic works, the question of the integrity of the Synopotic Gospels deserves renewed exploration. This does not imply that we are forced to agree with Celsus or Porphyry, or that we have to accept Marcion's assertion about the deliberate falsification of the gospels. But the orthodox Christian witnesses deserve to be treated with the same degree of credit and with the same amount of suspicion as the writings of their heretical adversaries. Let us not forget that the Book of Jeremiah was revised and edited on several occasions until the beginning of the Common Era. ${ }^{37}$ We also should not forget the Christian attacks upon the Jews, claiming that they had modified certain messianic sections of their scriptures (Justin Dial. 71-73). ${ }^{38}$ Finally, we should remember that the Gnostic theologian Ptolemy charged that the Law of Moses had later been interpolated. ${ }^{39}$

Concerning the New Testament texts, let us move to Origen's testimony that besides the four inspired Evangelists there were others, already criticized by Luke, who had only "tried" to write gospels. ${ }^{40}$ (Origen then comments on the prologue of Luke.) By this statement, Origen furnishes us with a testimony to the variety of gospels in circulation at his time; he provides definitive evidence for the antiquity of these gospels as he admits that they were written prior to the composition of Luke. Another text from Origen is pertinent here. ${ }^{41}$ According to Origen, Celsus affirmed that certain Christians, as if drunk with wine, revised the gospels. Celsus claims that these revisions were repeated "three or four or several times over" for apologetic purposes ("to deny difficulties in face of

${ }^{37}$ Cf. J. G. Janzen, "Double Readings in the Text of Jeremiah," HTR 60 (1967) 433-47; cf. the summary of his dissertation, "Studies in the Text of Jeremiah," HTR 59 (1966) 447; and the second part of C. Wolff's Jeremia im Früjudentum und Urchristentum (TU 118; Berlin: Akademie, 1976).

${ }^{38}$ Cf. M. Simon, Verus Israel. Étude sur les relations entre Chrétiens et Juifs dans l'empire romain (135-425) (Paris: Boccard, 1964) 185. Simon stresses Christian interpolations rather than Jewish excisions.

${ }^{39}$ Cf. the Letter to Flora, 4.1 - 2. Cf. Ptolémée, Lettre à Flora, analyse, texte critique, traduction, commentaire et index grec (ed. G. Quispel; SC 24 bis; Paris: Cerf, 1966) 20-33.

${ }^{40}$ Hom. Luke 1:1-2. Cf. Origène, Homélies sur S. Luc: Texte latin et fragments grecs: Introduction, traduction et notes (eds. H. Crouzel, F. Fournier and P. Périchon; SC 87; Paris: Cerf, 1962) 99 - 106; Merkel, Pluralité des Évangiles, 7-8.

${ }^{41} \mathrm{C}$. Cel. 2.27: "After this he says that "some believers, as though from a drinking bout, go so far as to oppose themselves and alter the original text of the gospel three or four or several times over, and they change its character to enable them to deny difficulties in face of crticism." Translation from H. Chadwick, Origen. Contra Celsum translated with an Introduction and Nores (3d ed.; Cambridge: Cambridge University Press, 1980) 90. 
criticism"'). Origen responds by admitting that there were revisions, but notes that such modifications were few, affirming that he knew those of Marcion, Valentinus, and Lucian (an independent Marcionite). Thanks to Irenaeus and Clement, we can expand this list. ${ }^{42}$ The fact of these modifications cannot be doubted. We have positive knowledge of examples from both the second and first century CE. The question arises: why are the revisions of the second century less legitimate than those of the first century? Are they not of the same nature? Are not the modifications from the first century as ideological and apologetic as those of the second century? After all, the canonical gospels were written to transmit a message to their time in order to legitimize the community which transmitted them.

One should not forget that the most extensive exegetical efforts of the Fathers were devoted to the solution of discrepancies between the gospels of the New Testament whose texts had become untouchable because they were canonical. ${ }^{43}$ Prior to the constitution of the canon, more drastic but simpler solutions were customary. ${ }^{44}$ Harmonies were produced in order to overcome the embarrassment of a multiplicity of contradictory texts. As D. A. Bertrand has recently shown, ${ }^{45}$ the Gospel of the Ebionites must have been a harmony of Matthew, Mark, and Luke, produced prior to the Diatessaron of Tatian (who also includes John). Other examples of harmonization are evident in the modifications

${ }^{42}$ Irenaeus $A d v$. haer. 3.11.7. Irenaeus attacks those who concentrate on one gospel alone and understand it badly. But he adds, "So great is the authority attached to these Gospels [the canonical Gospels] that the heretics themselves give witness to them and each of them tear away a bit to attempt to strenthen his argument." Cf. Adv, haer. 3.2.1. According to the letter of Clement of Alexandria fol. $1^{v}$ lines $2-10$. Carpocrates would have falsified the secret gospel written by the Evangelist Mark. Cf. Morton Smith, Clement of Alexandria and a Secret Gospel of Mark (Cambridge: Harvard University Press, 1973) 446-52. Furthermore, we know that Tatian modified the synoptic sayings in an encratite sense. Cf. L. Leloir, Ephrem de Nisibie. Commentaire de l'Évangile concordant ou Diatessaron traduit du syriaque et de l'arménien. Introduction, traduction et notes (SC 121; Paris: Cerf, 1966) 12. According to Eusebius of Caesarea Hist. eccl. 4.19.6, he would have modified several expressions of the apostle Paul. Tertullian Adv. Marc. 4.5 rebukes Marcion for constantly changing his text of the Gospel.

${ }^{43}$ Cf. O. Cullmann, "Die Pluralität der Evangelien als theologisches Problem im Altertum. Eine dogmengeschichtliche Studie," ThZ 1 (1945) 23-42, taken up in Cullmann, Vorträge und Aufsätze 1925-1962 (ed. K. Fröhlich; Tübingen: Mohr, 1966) 548-65; H. Merkel, Widersprüche zwischen den Evangelien. Ihre polemische und apologetische Behandlung in der Alten Kirche bis zu Augustinus (WUNT 13; Tübingen: Mohr-Siebeck, 1971).

${ }^{44}$ To mention only three examples, the Epistula apostolorum, the Apocalypse of Peter and the Protevangelium of James know several or all of our canonical gospels, but they use them so liberally that they must not have yet recognized canonical normativity. Note also the hesitations of Serapion of Antioch regarding the value and the authority of the Gospel of Peter. Cf. Eusebius of Caesarea Hist. eccl. $6.12 .2-6$.

${ }^{45}$ Cf. D. A. Bertrand, ' L'Évangile des Ébionites: une harmonie évangélique antérieure au Diatessaron," NTS 26 (1979-80) 548-63. 
introduced by the gospel writers themselves. Consider Luke 1 and 2. There Luke modifies a text which located both the annunciation and the birth of Jesus at Nazareth. Luke retains the locale of Nazareth for the annunciation but replaces the story of the birth at Nazareth with an account of the proclamation to the shepherds and the birth at Bethlehem. ${ }^{46}$ Luke thus revised the earlier tradition according to his missionary concerns and apologetic concerns. This fact must be faced. Celsus is not entirely wrong: there were indeed believers who corrected the sources of the gospels as well as the gospels themselves ( $\tau$ ivò

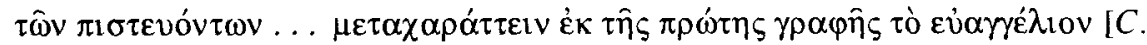
Cel. 2.27]).

Another problem is presented by Marcion. According to Tertullian, Marcion reproached the Church for possessing only a modified edition of Gospel of Luke. Tertullian writes, "I say that my Gospel is the true one; Marcion that his is. I affirm that Marcion's Gospel is adulterated; Marcion, that mine is." 47 Since Marcion is considered a heretic, Christian scholars usually side with Tertullian and accuse Marcion of modifying the gospel himself. From a historical perspective we must acknowledge that Marcion has apparently corrected his gospel. But we should also admit, as R. J. Hoffmann does, ${ }^{48}$ that the ecclesiastical form of this gospel is possibly not its oldest version.

The story of the origin and development of the Gospels of Matthew, Luke, and John proves that Celsus was not wrong when he states that the believers had modified their holy scriptures. Such rewriting was tolerated until the definitive constitution of the canon which then, and only then, outlawed further revisions of the text. The transgression of Marcion, the Ebionites, Valentinus, and Tatian was not their attempt to modify the gospels, but their accomplishing such attempts too late.

\section{THE JUSTIFICATION OF THE CANON}

At the end of the second century it became necessary to legitimate the selection of our four gospels. Justifications for this choice were duly produced. One reason was drawn from biblical exegesis (with reference to the four beasts of Ezek 1:10 and $\operatorname{Rev} 4: 7$ ). Other reasons were provided on the basis of legends of a nature that hardly differs from that of the apocryphal acts. Irenaeus and

\footnotetext{
${ }^{46}$ Concerning the prehistory of Luke $1-2$, see my commentary on the Gospel of Luke, which will appear in the EKKNT collection and in the Hermeneia series.

${ }^{47}$ Adv. Marc. 4.4. I am citing Peter Holmes' translation of The Five Books of Quintus Sept. Flor. Tertullianus against Marcion (Ante-Nicene Christian Library 7; Edinburgh: Clark, 1868) 183-84.

${ }^{48}$ R. J. Hoffmann, "Marcion: on the Restitution of Christianity: An Essay on the Development of Radical Paulinist Theology in the Second Century" (Ph.D. diss., Oxford University, 1982) 127-64. I am using a photocopy of this dissertation "supplied by the British Library Document Supply Centre." The work was published in 1983 by Scholars Press in the United States.
} 
Epiphanius argue that the personal history of each Evangelist enabled him to write a gospel. ${ }^{49} \mathrm{We}$ are also told how the different testimonies given by each gospel writer strengthen and complement one another. In some cases these legends went so far as to construct an entire history of successive periods of darkness and revelation. Thus the gospels were written chronologically to dispel another recurring period of darkness and to cast again the light of divine revelation. ${ }^{50}$

Paradoxically, the canonicity of the four gospels was justified through apocryphal legends. It is my hope that today the study of the apocrypha will enable us to renew the study of the canonical gospels. ${ }^{51}$

\section{CONCLUSION}

I see two tasks for exegetical scholarship at the end of this century. First, a scientific integration of several disciplines is needed. Specialization is already revealing its limitations. Textual critics should reach back into the discipline of codicology and forward into the field of hermeneutics. The history of the canon must be combined with the history of the reception of canonical writings, for the canon is at the same time the consequence and the cause of the existence of the gospels. As the dividing line between Urchristentum and ancient Christianity becomes more and more artificial, New Testament scholarship and the discipline of patristics must join hands. The exegetical comment of a Church Father, insofar as it reflects on an initial problem, may be a better and more pertinent interpretation than modern scholarly commentary. Palaeography and theology should be intimately related. Through its very material data a codex may teach us the thought of the first Christians; similarly, a simple textual variant can reveal much concerning the "encratism" of a social group. Much will be gained by perceiving the mundane features of the formation of the gospels.

The second task for exegesis is to move exegetes towards a more critical self-examination-an increased awareness of their own prejudices. Exegetes must impose upon themselves the regimen recommended above: a respect for

${ }^{49} \mathrm{Cf}$. Irenaeus $A d v$. haer. 3.1.1-2.1 (a short note on the identity of the four Evangelists and the circumstances of the redaction of their Gospel); 3.11.8-9 (the justification of the four Gospels by the four regions of the world, and placing the four Gospels in relation with the four living beings in Rev 4:7); Epiphanius Pan. 51.6.6-7.8. These texts are cited, translated and commented upon by Merkel, Pluralité des Évangiles, 110-15.

50 This is the case with the testimony of Epiphanius noted in the preceding note.

${ }^{51}$ W. Schmitals, Einleitung in die drei ersten Evangelien (De Gruyter Lehrbuch; Berlin: De Gruyter, 1985) hardly integrates Christian apocryphal literature into his research concerning the origin of the canonical Gospels. But the scholar to whom these pages are dedicated rightly gives these writings great attention. Cf. H. Koester, "Apocryphal and Canonical Gospels," HTR 73 (1980) $105-30$. 
the historical contingencies of the canonical texts and a corresponding integration of several scholarly disciplines. In so doing, they will adopt an attitude which respects not only the incarnation of the Son, but also the incarnation of the documents that bear witness to him. 